\title{
Microbial synthesis of macroparticulate matter
}

\author{
Bopaiah A. Biddanda \\ Institute of Ecology, University of Georgia, Athens, Georgia 30602, USA
}

\begin{abstract}
From a re-examination of the role of microorganisms in de novo particle synthesis in sea water, I present evidence that presence of active bacteria is necessary for aggregate formation. Particle formation, in filtered sea water kept idle, circulated and bubbled (without or with additional Dissolved Organic Matter or Dissolved Organic Matter + Particulate Organic Matter), was found to occur only in the presence of bacteria. Bacteria growing at the expense of DOM present, formed large particles $>100$ microns by aggregation (bacterial aggregates) as well as by the aggregation of smaller particles into larger ones (bacterio-particle aggregates) $>1 \mathrm{~mm}$. Parallel killed treatments did not show any particle formation of the type of Baylor and Sutcliffe (1963), Sheldon et al. (1967) or Krank and Milligan (1980). This phenomenon of microbial macroparticulate matter synthesis could be the major pathway by which carbon and energy is transferred from the micro to the macro food webs in aquatic ecosystems.
\end{abstract}

\section{INTRODUCTION}

In the oceans, particulate organic carbon (POC) amounts to about $2 \times 10^{16} \mathrm{~g}$ which is 5 times more than phytoplankton biomass and 10 times less than dissolved organic carbon (DOC; Parsons, 1963; Cauwet, 1978). The concentration of dissolved organic carbon in sea water is usually within the range of 1 to $5 \mathrm{mg} \mathrm{l}^{-1}$ but considerably higher values are often encountered in coastal waters and in lakes (Wetzel et al., 1972). Riley (1963) concluded that there is a flexible system of reversible reactions allowing living organisms to draw upon a reservoir of organic carbon and replenish it in many ways. This was suggested as the mechanism that has tended to stabilize the aquatic environment by providing food resources for living organisms over more extended periods of time than that over which a single phytoplankton bloom could be sustained by the environment.

Baylor and Sutcliffe (1963) presented evidence for de novo synthesis of particles from dissolved organic matter in sea water by the action of rising bubbles and also showed that these particles could support the growth of brine shrimp, Artemia sp. De novo synthesis of particles from DOC has been attributed to bubble formation associated with bacterial activity (Riley, 1963). Menzel (1966) in a re-evaluation of these findings, concluded that bubbling per se was not a causative agent in the conversion of DOC to particulate form, as he was not able to produce a significant quantity of particles (over those produced in his unbubbled treatments) by bubbling. Barber (1966) found that sterile (bacteria-free) sea water did not form particles when bubbled. Subsequently, Batoosingh et al. (1969) tried to sort out the confusion and reported the necessity for particles in the size range of 0.22 to 1.2 microns (size range of bacteria) to serve as nuclei in the formation of larger particles during bubbling. Sheldon et al. (1967) suggested that bacterial growth and aggregation are responsible for formation of particles in filtered sea water. According to Nishizawa (1969), the mechanism also seems to require the presence of at least a few species of bacteria in the original filtrate, suggesting a possible bacterial syntropism occurring in aggregate formation. Jensen and Sondergaard (1982) reported significant abiotic formation of particles from algal extracellular products, cautioning this may lead to overestimates in heterotrophic production estimates made by the usual labelling and recovery by filtration techniques. However, flocculation may have been influenced by the extreme changes in ionic concentrations that they must have induced during their study of this phenomenon. Cauwet (1981) is of the opinion that physical and bacterial processes are responsible for formation of aggregates by bubbling. Particle aggregation has been attributed to physicalchemical flocculation (Krank and Milligan, 1980) and aggregation of microorganisms enhanced by high DOC concentrations (Paerl, 1975). Recently, Robertson et al. (1982) provided experimental evidence that bacteria using DOC from seagrass rapidly form detritus-like 
aggregates ranging in size from a few microns to few millimeters. They did not notice any abiological flocculation of organic matter. However, they (like Krank and Milligan, 1980) did not have 'killed control' treatments. Thus the question of the mechanism of aggregate formation from DOC in the sea is largely unresolved.

Microzonal alkalinization due to deaminating activity of bacteria has also been argued and demonstrated to be responsible for the formation of oolith-like crystals of calcium carbonate which subsequently adsorb dissolved organic matter, resulting in the formation of fuzzy flakes (Sieburth, 1965). In a recent development, Johnson and Cooke (1980) presented photographic evidence for organic particle formation from bubble dissolution in sea water. I have not examined the above two modes of particle formation in this study.

Since aggregates of bacteria and non-living particulate matter containing bacterial biomass are more accessible to macro-consumers than free-living bacteria, the question of the origin and fate of seston in the sea is closely tied to that of the interaction between micro and macro food webs (Pomeroy, 1984). Also, physical-chemical processes promoting exchange between dissolved and particulate organic pools of carbon in the Ocean have often been used by ecologists to explain the calculated short-fall in the amount of particulate food required by macro food chains and that available to them in the form of phytoplankton cells and detritus (Riley, 1963). It is, therefore, ecologically important to examine the formation and fate of marine seston.

In this study, I have re-examined particle formation in filtered sea water, filtered sea water with added DOM and filtered sea water with added DOM + POM, paying particular attention to the role of microorganisms in the process. I present evidence obtained from simple but readily reproducible experiments that show the central role that bacteria play in aggregate formation of the type of bacteria aggregates (Sheldon et al., 1967; Paerl, 1975; Robertson et al., 1982) and bacterio-particle aggregates (Krank and Milligan, 1980; Newell et al., 1981; Robertson et al., 1982).

\section{MATERIAL AND METHODS}

Sea water for the experiments was collected from the Gulf Stream, off Georgia, USA. Sources for the organic matter inoculum, were seaweeds - Gracillaria and Ulva were obtained from out door culture tanks (K. Tenore, Skidaway Inst. Oceanogr.); Sargassum was collected from the open sea. All these were preserved at $-40^{\circ} \mathrm{C}$ until use in the laboratory. The organic inoculum was prepared by grinding approximately equal quantities (wet weight) of Gracillaria, Ulva, Sar- gassum in a mortar and pestle or a blender, and extracted in sea water. The extract was subsequently screened through nitex screens or millipore filters of appropriate sizes. No separate microbial inoculum was used. The sea water was prefiltered through a 0.45 micron millipore filter. The $\mathrm{pH}$ of the extract and that of sea water were measured prior to and after mixing and the changes were not greater than $0.5 \mathrm{pH}$ units. One liter Wheaton plastic Imhoff settling cones (Styrene acrylonitrile) were used for the experiments, and circulation was provided by means of a water pump with a wormgear impeller, and bubbling by forcing laboratory air supply through glass frits located at the bottom of the column. The air supply was passed through a small chamber containing the desiccant silica gel, and then through a glass fiber filter, to trap water vapour and associated impurities. Chiefly, three sets of experiments were conducted:

Experiment 1: 'Particle formation in filtered sea water'. Three replicates of filtered sea water (millipore filters, 0.45 microns) were kept still, circulated or bubbled. Initial DOC concentration was approximately $2 \mathrm{mg} \mathrm{l}^{-1}$. This experiment recorded particle formation from filtered sea water and also served as a background for Experiments 2 and 3.

Experiment 2: 'Effect of DOM enrichment on particle formation'. Three replicates of filtered sea water plus seaweed organic extract (filtered through millipore filter of pore size 0.45 microns) were kept still, circulated or bubbled. Initial DOC concentration was approximately $10 \mathrm{mg} \mathrm{l}^{-1}$.

Experiment 3: 'Effect of DOM + POM addition on particle formation'. Three replicates of filtered sea water plus DOM plus POM (seaweed extract filtered through nitex screens with pore sizes 10,50, $100 \mathrm{mi}$ crons, and the filtrate used as the DOM + POM source) were kept still, circulated or bubbled. Initial DOC concentration was approximately $22 \mathrm{mg} \mathrm{l}^{-1}$. This experiment recorded particle formation of the type in Experiments 1 and 2 , as well as any particle size increase by interparticle adherence.

All the treatments (kept still, circulated and bubbled are the three treatments in each of the experiments), had duplicate killed treatments (10 ppM mercuric chloride in 1 and 2; 100 ppM in 3). Because in Experiment 3, I attempted to approximate the composition and concentration of organic matter as in Krank and Milligan (1980), it was found that $10 \mathrm{ppM} \mathrm{HgCl}_{2}$ was inadequate for maintaining complete sterility over the entire duration of the experiment. The killed controls in Experiments 1 and 2 especially recorded particle formation without any interference from already existing (introduced) particles. To check if mercuric chloride was a valid control, it was introduced into live Experiments 1, 2 and 3 after they had formed aggre- 
gates and examined for any effect on existing aggregates. While it did arrest further formation of aggregates, it did not cause breakdown of existing aggregates. It was possible that the impeller of the pump used in circulation, especially in Experiment 3, broke up the large aggregates formed. Hence the Experiment 3 circulation effect step was repeated using a 11 beaker and inducing circulation by means of magnetic stir bars in both the live and killed treatments. To study the 'wall effect', microscope slides were suspended in each of the treatments and examined by epifluorescence microscopy after staining with acridine orange for microbial growth.

All the experiments were run time-course and sampling was done for eight days. A 0.5 to $1.0 \mathrm{ml}$ sample of the suspension was filtered onto 0.22 micron black Sartorius filters under very low suction $(<5 \mathrm{PSI})$ and stained with acridine orange prior to observation under epifluorescence microscopy (up to 20 fields, each $70 \times 70$ microns were counted on each slide) for free bacteria, flagellates, bacteria in aggregates and bacteria on particles (Hobbie et al., 1977). Bacteria present on the underside of the aggregates have not been included in the counts and this may be expected to have resulted in an underestimate. Samples were observed under phase contrast microscopy also, but it was found that epifluorescence microscopy as used here (with acridine orange staining), was better at revealing the details of the microbiology of the aggregates than phase contrast. Sampling of the aggregates in intact condition always presented a problem as they would invariably break up during transfer to the filtration tower. However, since the composition of the aggregates formed was homogeneous, it did not affect what was observed microscopically. Scanning electron microscopy was done to examine the ultrastructural details of microbial adhesion to one another and to the particles. DOC estimation was done by the method of Menzel and Vaccaro (1964) and no chemical characterization of this algal derived extract was made. The unsually large concentrations of DOM and POM in Experiments 2 and 3 were necessitated because I wished to duplicate and reexamine earlier work by others. Counts per $\mathrm{ml}$ of the suspension were calculated at $95 \%$ confidence level. Using Statistical Analysis System (SAS User's Guide, 1982), a multiple regression analysis and an analysis of variance were performed on the data to examine how the treatments (still, circulated, bubbled) and experiments (filtered sea water, sea water plus DOM, sea water plus DOM plus POM) affected particle yield. Duncan's multiple range tests (SAS User's Guide, 1982) were done to look for significant treatment effects within each experiment, and for experimental effects amongst the three experiments.

\section{RESULTS}

Rapid build up of bacteria was observed in all the live treatments (Table 1). Killed parallel treatments remained unchanged through time and did not show particle formation of any type. The treatments in Experiment 1 with only filtered sea water did not form any particles visible to the naked eye. However, bacteria numbers in the filtered sea water increased from very negligible ones to steady state numbers of approx $10^{5}$ to $10^{6} \mathrm{ml}^{-1}$ in $96 \mathrm{~h}$, and few bacterial aggregates of very small size 3 to 10 microns could be observed under the microscope. Experiment 2, having an input of DOM, showed a very rapid increase in bacterial numbers which reached steady state numbers of approx $10^{6}$ to $10^{7} \mathrm{ml}^{-1}$ in just over $48 \mathrm{~h}$. In the columns that were circulated and bubbled, aggregates in suspension became visible to the eye in just over $24 \mathrm{~h}$, while in the treatment that was kept still, the aggregates tended to form at the bottom. The aggregates were usally smaller than 10 microns but occasional ones as large as 1 to $2 \mathrm{~mm}$ were also seen. While turbulence caused either by circulation or bubbling did appear to encourage aggregate formation, all three treatments yielded identical types of bacterial aggregates. In Experiment 3, with an input of DOM as well as POM (results of less than 50 micron size POM addition given in Table 1), the bacteria showed the very rapid rate of increase both as free and attached forms (reaching steady state numbers of approx. $10^{7}$ $\mathrm{ml}^{-1}$ in roughly $48 \mathrm{~h}$ ). Particle aggregation was discernable in about $48 \mathrm{~h}$ and was marked by $48 \mathrm{~h}$ (aggregates as large as 1 to $5 \mathrm{~mm}$ were seen). Here, 3 types of particles were commonly observed under the microscope: free bacteria, bacterial aggregates and bacteterio-particle aggregates. The aggregate formation appeared to be faster in the treatments with turbulence. However, all treatments formed the three types of particles described above. In another repetition of the experiment, turbulence caused by magnetic stirring bars yielded particles of the same size and quality (general morphology and microbiology) as in the circulated and bubbled treatments.

Microscopic study indicated that aggregates were formed by attachment of bacterial cells while attached to one another. In Expt. 1 and 2, unlike the observations of Robertson et al. (1982), who refer to an amorphous core of particulate matter, we observed the aggregates to be consisting of only bacteria (Fig. 1). We did however observe amorphous POM matrix in the bacterio-particle aggregates obtained in Experiment 3. But these particles were clearly identified as the seaweed particles that were introduced in the inoculum (Fig. 2).

In both Experiments 2 and 3, after Day 4, flagellates 
Table 1. Time-course numbers per $\mathrm{ml}$ of free bacteria (FR BAC), flagellates (FLAG), bacteria in aggregates (BAC IN AGG), and bacteria on particles (BAC ON PART). Numbers in parentheses: standard error

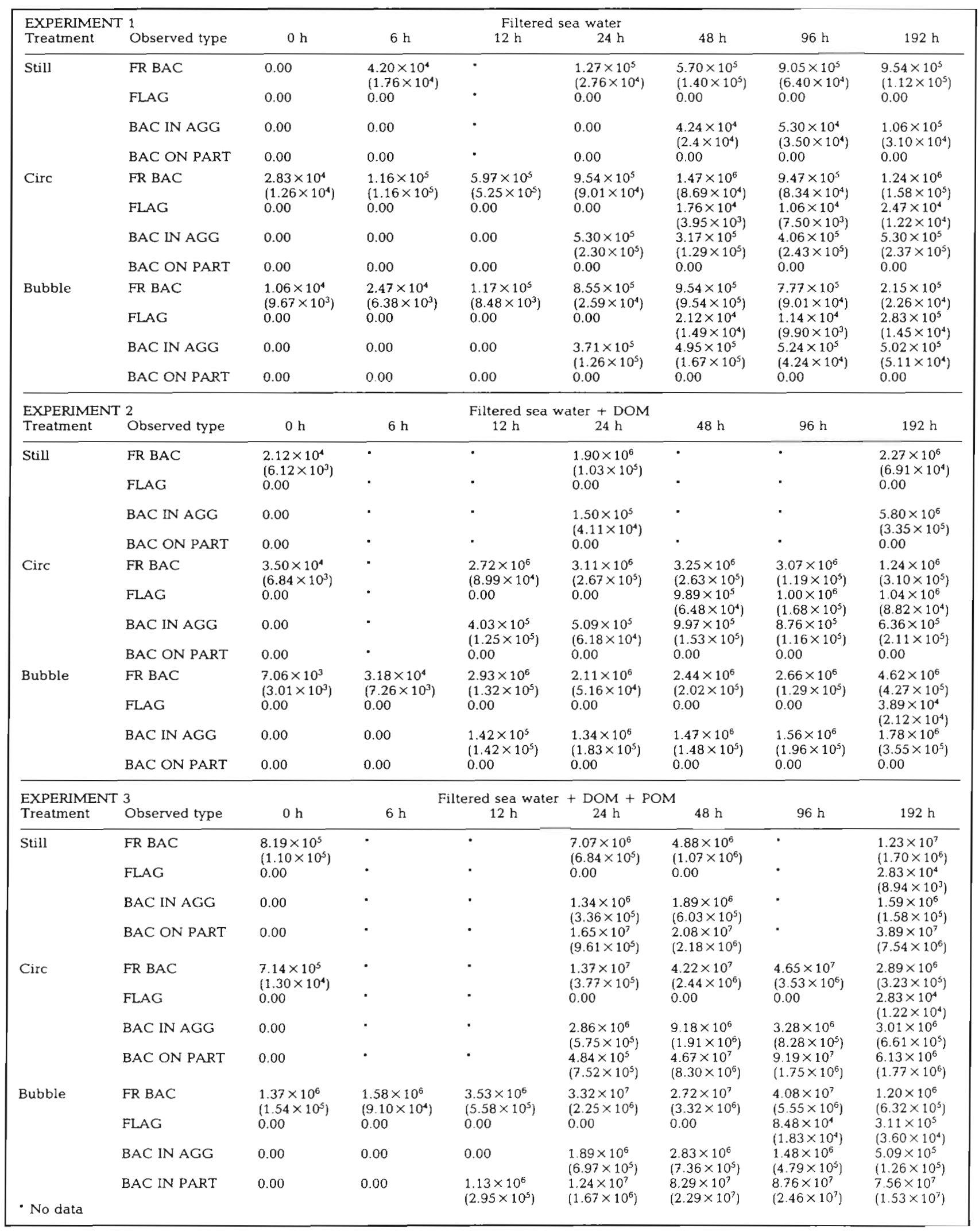



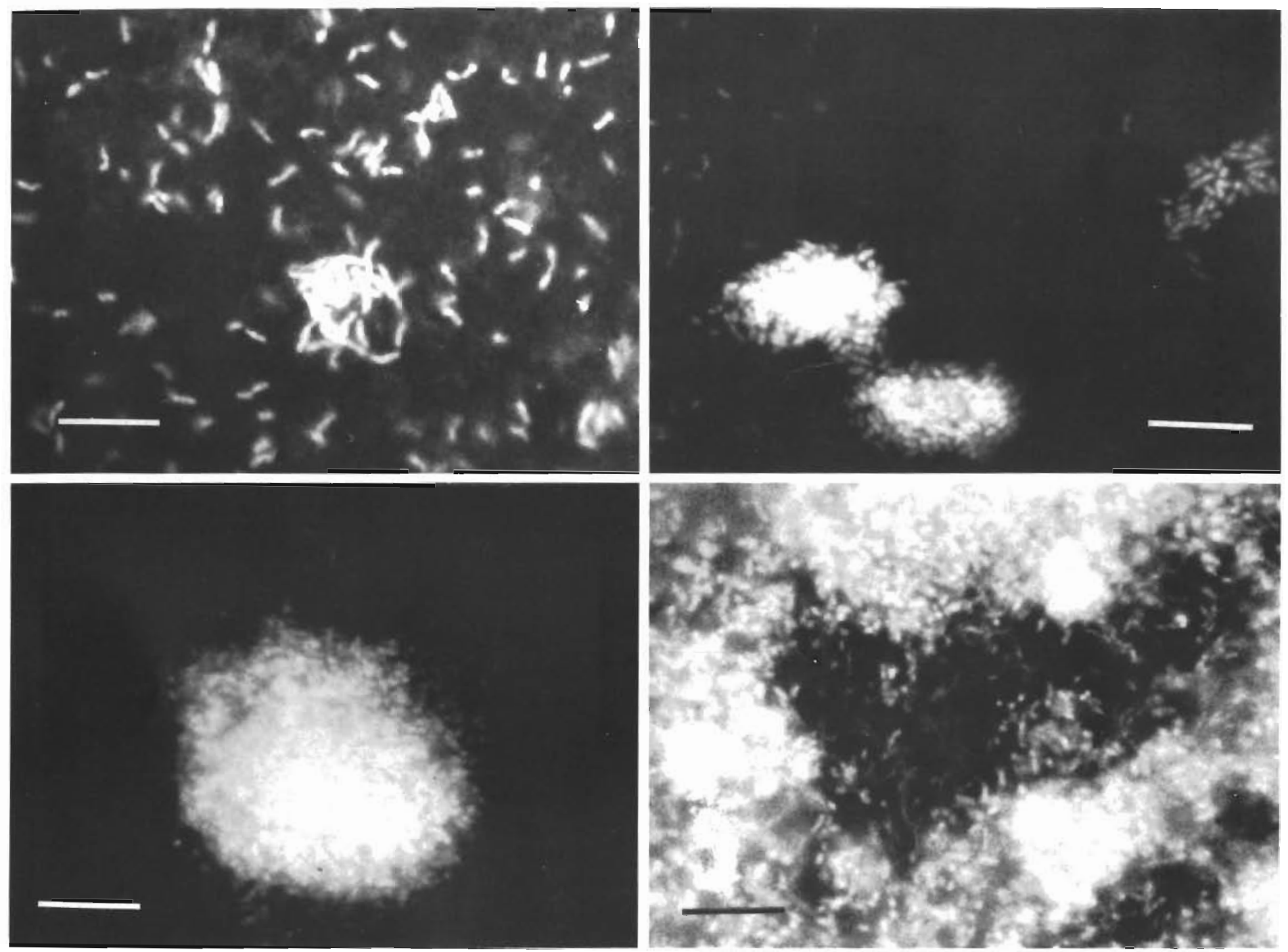

Fig 1. Bacterial aggregate formation in filtered sea water with added seaweed DOM. Upper left: 12 h; upper right: $24 \mathrm{~h}$; lower left: $48 \mathrm{~h}$; lower right: $192 \mathrm{~h}$. Aggregates consist only of bacterial biomass. All pictures taken under epifluorescence after staining with acridine orange (all scale bars $=10$ microns)

often formed a significant population occurring free, attached to the aggregates and in clumps. Appearance of flagellates was most dramatically reflected in a rapid decrease in numbers of free bacteria. In a case study, an inoculum having flagellates was introduced into a $4 \mathrm{~d}$ old system (Experiment 2) that did not have any flagellate population. In less than $48 \mathrm{~h}$ there was a decrease in numbers of bacteria from $10^{7} \mathrm{ml}^{-1}$ to $10^{5} \mathrm{ml}^{-1}$, confirming that the fluctuations in bacterial numbers were affected by flagellate grazing activity.

In Experiment 3, the seaweed particles were initially colonized by bacteria and then particle size increase was affected by means of interparticle bacterial bridges (Fig. 2). This process generally took about $12 \mathrm{~h}$ and consequently particle aggregation could be made out only after $14 \mathrm{~h}$, unlike the observations of Krank and Milligan (1980), who described immediate flocculation due to physico-chemical processes. Moreover, the $14 \mathrm{~h}$ required for the initiation of aggregation process and the total absence of aggregate formation in the killed treatments (Fig. 3) are evidence for the important role of biological processes in aggregate formation.

The suspended glass slides that were studied as an index for microbial activity on the walls indicated greater bacterial concentrations here than in suspension. Also, when grazers (flagellates) appeared, they tended to concentrate on the surface in greater numbers than compared to the water column. While a considerable proportion of the aggregates was always in suspension, they also tended to occur attached to the walls of the container (between 10 and $60 \%$; lower 

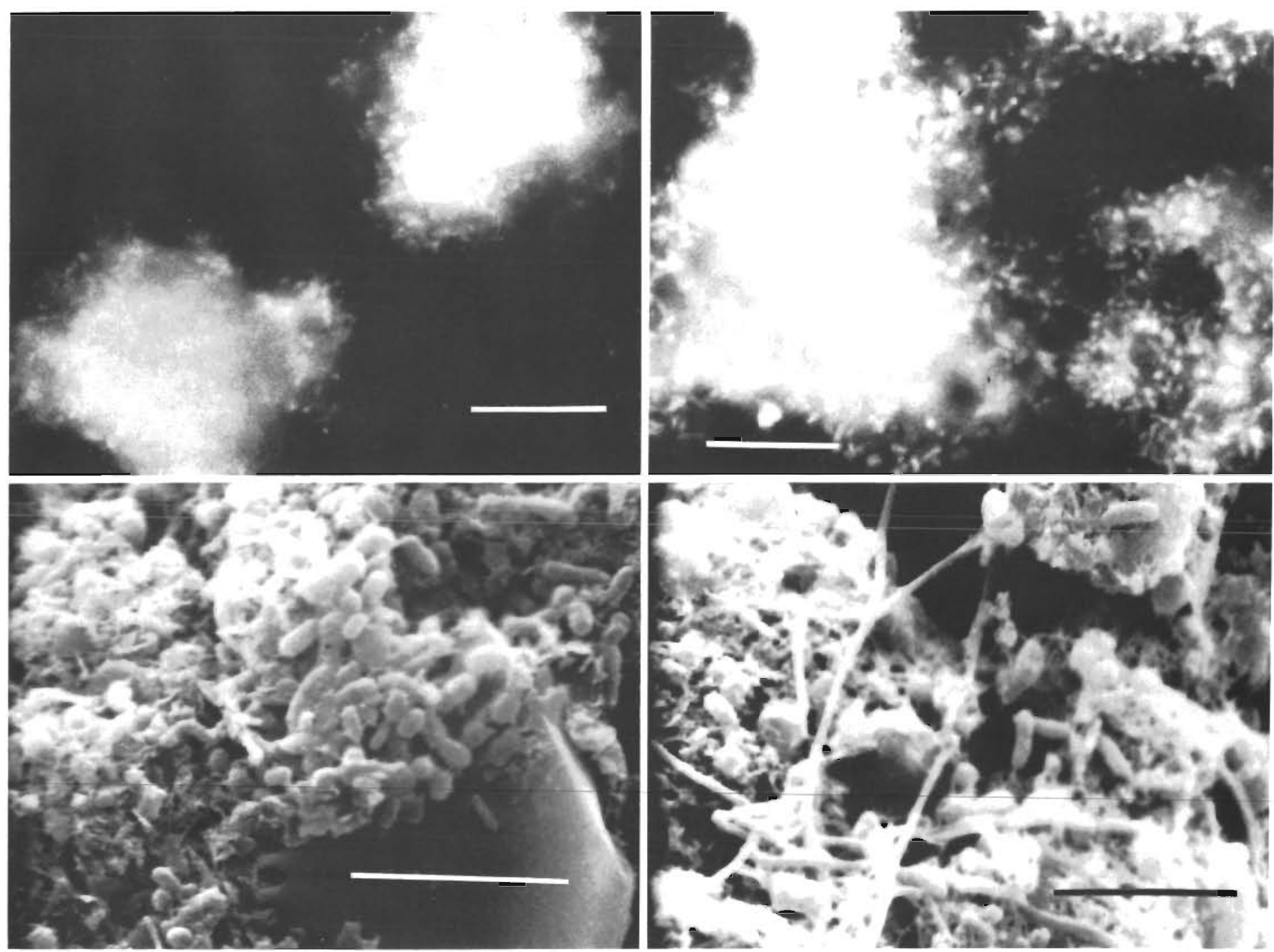

Fig. 2. Bacterio-particle aggregate formation in filtered sea water with added seaweed DOM and POM. Upper left 24 h; upper right $48 \mathrm{~h}$; lower left $96 \mathrm{~h}$; lower right $192 \mathrm{~h}$. Formation of seaweed particle aggregates due to bacteria colonization followed by development of interparticle bacterial linkages. Pictures upper left and upper right taken under epifluorescence after staining with acridine orange (scale bars $=20$ microns). Pictures lower left and lower right are scanning electron micrographs (scale bars $=5$ microns)
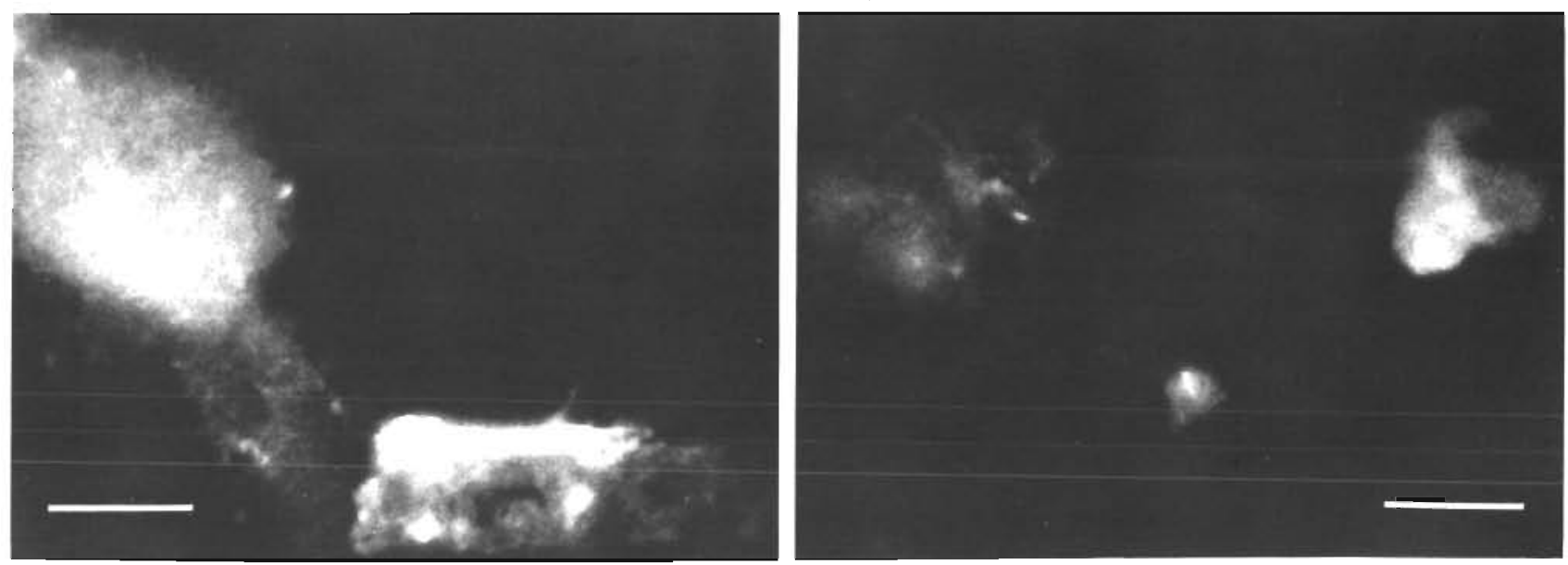

Fig. 3. Control experiment (sea water $+\mathrm{DOM}+\mathrm{POM}+\mathrm{Hgcl}_{2}$ ) result. Left: $0 \mathrm{~h}$; right: $192 \mathrm{~h}$. Arrested bacterial growth (bacteria which were present in the 50 micron-screened seaweed inoculum); absence of aggregate formation (scale bars $=20$ microns) 
Table 2. Summary of multiple regression analysis and analysis of variance

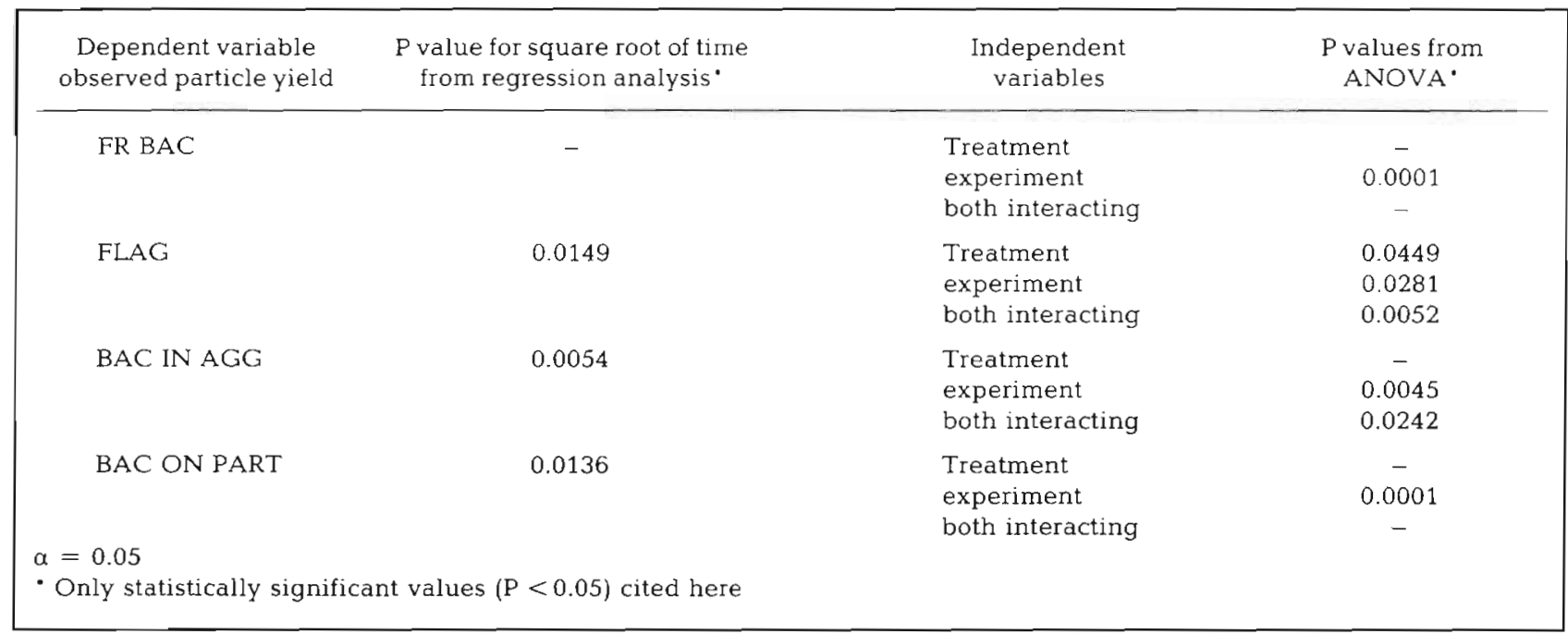

Table 3. Summary of Duncan's multiple range test

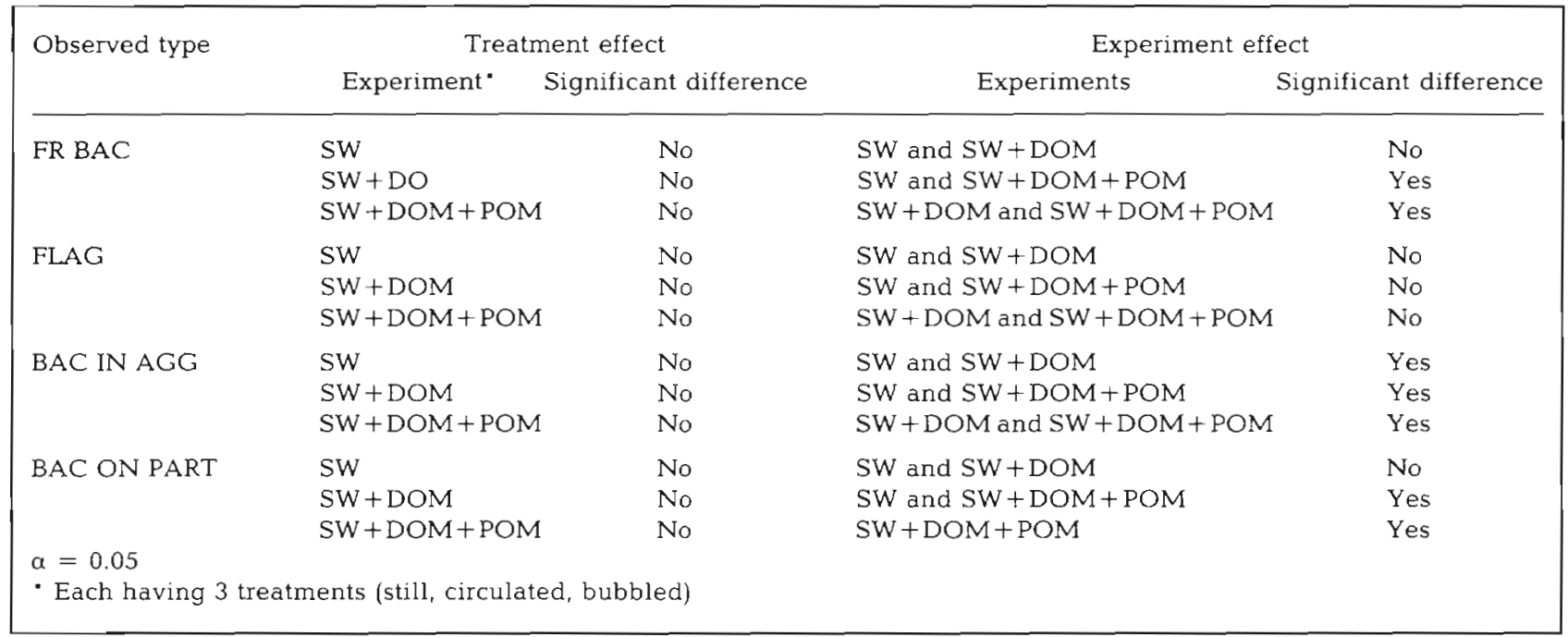

values when flagellate numbers are high and higher values otherwise), confirming that aggregates containing bacteria are sticky.

The multiple regression analysis and analysis of variance results are summarized in Table 2 . The square root of time and the experimental condition were consistently significant predictors of the observed particle yield, while treatment condition was a significant predictor of flagellates alone. Both treatment condition and experimental condition acting together were good predictors of flagellates as well as bacteria in aggregates. The Duncan's multiple range test results summarized in Table 3 showed no significant treatment effect $(\alpha=0.05)$ within any of the experiments, which is supportive of the argument that biological factors are more important than purely physical ones in determining the observed particle yield.
The tests, however, showed significant differences (significant experiment effect at $\alpha=0.05$ ) between observed particle yield for the three experimental conditions. This is supportive of the argument that enhanced DOM or the addition of POM affect the observed particle yield. Exceptions to this were in the cases of: (1) free bacteria in Experiments 1 and 2 (excessive free bacteria in Experiment 2 probably transformed rapidly into another observed type, bacteria in aggregates); (2) bacteria on particles in Experiments 1 and 2 (both of which had no input of POM, and therefore recorded zero for bacteria on particles). Variations between treatments within the same experiments, may be partly attributed to the fact that there was no way to control the onset of the flagellate population or its growth from then on. However, certain observations can be made on the general trends with 
Table 4. Dissolved organic carbon changes $\left(\mathrm{mg} \mathrm{I}^{-1}\right)$

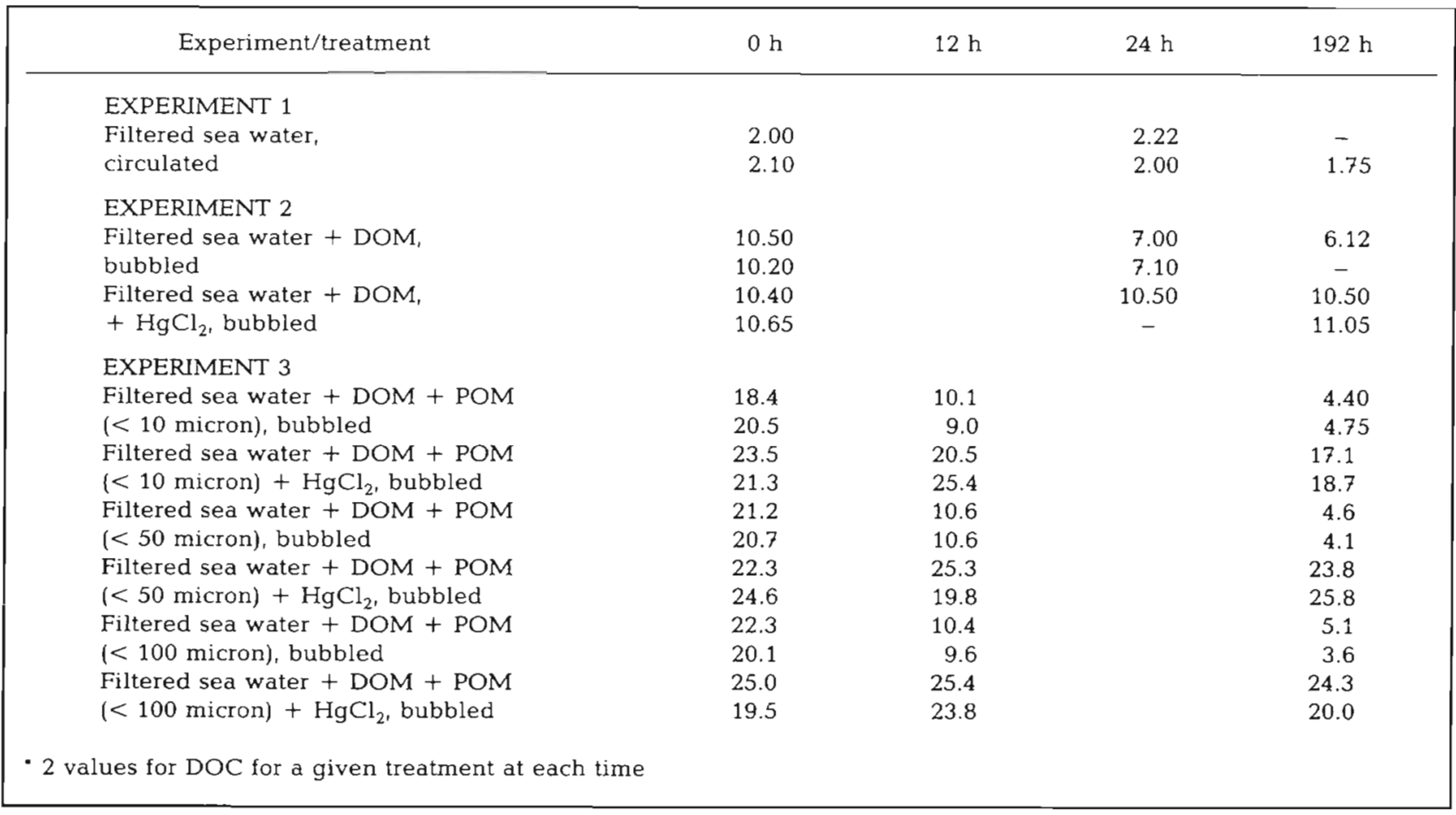

confidence, viz., within the different treatments (kept still, circulated, bubbled) in the same experiment, the amount and type of aggregate formation is the same; and that between experiments $(1,2,3)$, the differences in the yield are very marked.

Changes in DOC concentration (Table 4), while not significant in Experiment 1, in Experiments 2 and 3 show considerable decrease with the increase in number of bacteria and formation of aggregates. $30 \%$ and $50 \%$ decreases in the original DOC levels were observed in Experiments 2 and 3 respectively in $24 \mathrm{~h}$. In all killed treatments, the DOC level remained unchanged through time. In Experiment 3 this observation would indicate that there was no significant addition of DOC due to physical leaching from POM.

\section{DISCUSSION}

Pomeroy and Johannes (1968) concluded that organic aggregates were the loci of considerable metabolic activity in the oceans. Following this, Wiebe and Pomeroy (1972) observed that specific zones of increased microbial abundance do exist even in open ocean waters. According to Riley (1970), the visual appearance of most particles in the sea suggests two mechanisms by which they may have been formed: (1) adsorption of organic matter on inorganic particles and includes possible growth of inorganic-organic complexes, (2) particle formation involving bacteria and secretion of bacterial slimes which may trap additional particles. Electron microscopy studies by Pomeroy (1983) show numerous minute filaments (apparently of bacterial origin) linking particles together, which may explain the origin of large sea snow particles. Sheldon et al. (1967) ascribed bacterial aggregate formation as due to a few species. My scanning electron microscopy studies indicate this possibility, since I detected extension processes on spherical and fusiform bacteria but not on the rods which seem to achieve adherence by means of extracellular matrix probably made of mucopolysaccharides (Hobbie and Lee, 1979). While past work has indicated that bacteria attached to particles constitute $20 \%$ or less of the bacterial biomass and activity in coastal and open ocean systems (Wiebe and Pomeroy, 1972; Azam and Hodson, 1977), more recent work has not shown this. Kirchman and Mitchell (1982), Ducklow and Kirchman (1983), by working on the production of free and attached bacteria, found that the forms attached to particles were metabolically more active than free bacteria in marshes and vice versa in lakes and oceans. However, in all these environments, the epibacteria were more active on a per cell basis than free bacteria. Hodson et al. (1981), Moriarty (1979) and Pedros-Alio and Brock (1983) found it (using dissolved ATP uptake, muramic acid estimates and electron microscopy). respectively to be $50 / 50$ in different marine and fresh water environments. It is possible that the often recorded very small numbers of bacterial aggregates 
and bacterio-particle aggregates in the sea could be a reflection of (1) their faster turnover times and (2) inadequate sensitivity of the methods used in their collection and study.

Fenchel and Jorgensen (1977) concluded from their laboratory model experiments that detrital aggregates may be held together by bacterial capsular material and noted that enrichment of water with DOM enhances formation of such aggregates. As observed by Fenchel (1970), Pearl (1974) also provides evidence to show that DOC enrichment is linked to biologically mediated aggregation (Experiments 1 and 2 here). Bacterial secretions cause microorganisms to adhere to particulate substrates, enabling them to play a considerable role in the ecology of detritus (Paerl, 1973). Both free-floating and attached bacteria produce extracellular POC in the form of slime, capsular material and appendages which are derived from dissolved organic precursors (Paerl, 1974); and extensive networks of extracellular carbon may be deposited around individual cells and on the surfaces of particles supporting attached microbes (Paerl, 1978). Busch and Stumm (1968) found that aggregation of microorganisms resulted from interaction of polymers excreted by the microbial cell or exposed at its surface. Results of the experiments done here show that bacterial growth on DOM derived from macroalgae can lead to bacterial aggregates of a few mm in diameter and that bacterial growth around POM can even more rapidly lead to clumping of particles by formation of 'microbial bridges' into larger particles, several $\mathrm{mm}$ in diameter. While changes in DOC may be taken as an index of the rate of DOC conversion to POC in Experiments 1 and 2, it may be argued that it is strictly not possible in Experiment 3 since solution and leaching from the POM may be occurring simultaneously to DOC utilization by the microorganisms. However, the constant DOC level in the killed treatment would indicate that there was no significant contribution from leaching. I was not able to note a significant decrease in the DOC level in Experiment 1, corresponding with an increase in bacterial numbers. Sheldon et al. (1967) determined that less than $5 \%$ of DOC in a sea water sample is utilized by bacterial growth and the DOC estimation method used here was not sensitive enough to measure changes of a few micrograms per liter.

Under the experimental conditions employed, the only type of particle formation observed was by a rapid build up of bacteria, followed by bacterial aggregation (and bacterio-particle aggregation, when POM was present; Fig. 1 and 2). I did not observe sterile bacteriafree particles as described by Baylor and Sutcliffe (1963). My observations show that even in filtered sea water, bacteria rapidly increase from almost negligible numbers to approx. $10^{5}$ to $10^{6} \mathrm{ml}^{-1}$ in 3 to $4 \mathrm{~d}$. Trans- port of water-column bacteria by rising bubbles, concentration in the surface micro-layer (Carlucci and Williams, 1965; Weber et al., 1983) and ejection in jet drops (Blanchard and Syzdek, 1972), would provide a particle (bacteria) removal mechanism analogous to protozoan grazing or controlled filtration - the bacteria would grow back to their steady state numbers in filling the recently emptied niches. Bubbling, by physical turbulence and by providing a surface for attachment, may encourage bacterial aggregation, but by itself does not seem to be a significant means of particle production. Although I did not find the generation of particles free of bacteria (I observed exclusively microbial biomass in Experiments 1 and 2), it does not conclusively rule out this possibility under certain conditions, such as bubble dissolution. It does, however, strongly suggest a lesser importance for such abiotic particle formation as a means of DOM conversion. Conversely, it lays more emphasis on bacterial growth and aggregation as such a means.

I did not find evidence for formation of aggregates by physico-chemical flocculation of the type of Krank and Milligan (1980). A duplication of the Krank and Milligan (1980) experiment (Experiment 3 here, with the difference that I have made timecourse microscopic observations of the macroparticles produced) suggests the importance of bacteria in the process of aggregate formation. This is contrary to the conclusions of Krank and Milligan (1980). Sorokin (1974), working with aggregates over coral reef water column, concluded that aggregates were formed as a result of bacterial multiplication, since the presence of an antiseptic substance (Glutaraldehyde) did not promote bacteriacoral mucus aggregate formation. Newell et al. (1981), in their study of degradation and conversion of phytoplankton debris, observed that complex aggregates did not form in sterilized control vessels and concluded that aggregate formation probably is a process initiated by bacterial growth and adhesion to the particulate fraction of the cell debris. They also determined that, during the initial stages of the formation of bacterio-organic aggregates, the DOC component of the phytoplankton debris is utilized. Experiments done in this study confirm all these observations and emphasize the role of biological processes in aggregate formation in the sea. The laboratory produced aggregates here seem to resemble closely (morphology and microbiology) the aggregates produced during the later stages of degradation of Trichodesmium blooms at sea (Pomeroy, pers. comm.).

Bacteria, by forming aggregates and bacterio-particle aggregates, could serve as a food resource at several consumer levels. Such aggregation phenomenon enhances the efficiency of bacteria consumption by filter feeders (Seki, 1972). Silver and Aldredge (1981) 
observed that aggregates containing microorganisms rather than individual organisms themselves are a major food resource for macrozooplankton in oceanic waters. In coral reef environments, a potential energy source for reef zooplankton is the detrital aggregates of coral mucus (Qasim and Sankaranarayanan, 1970; Gottfried and Roman, 1983), which dominate the particulate matter in the water column (Johannes, 1967; Ducklow and Mitchell, 1979).

The notion of bacteria as 'sinks and links' (Pomeroy, 1974), the 'microbial recycling loop' (Williams, 1981) and the 'aggregate spinning wheel hypothesis' (Goldman, 1983) has provided new insights into the nature of the functioning of marine food chains. Nishizawa (1969) proposed that availability of deep-water organic material may be dependent not on the concentration in open water but on the localized concentrations in and near organic aggregates, and that aggregates are discrete centers of biological activity. Concentration of autotrophs, bacteria, protozoans and nutrients within natural marine aggregates are orders of magnitude higher than in surrounding water (Silver et al., 1978), which indicates that they may be self contained microenvironments of intense activity (Goldman, 1983). The work of Aldredge and Cox (1982) presented further evidence for enhanced primary productivity within marine snow as compared to the surrounding water. Considering all these aspects, Goldman (1983) suggested that the 'Wheel' may be spinning very rapidly in the organic aggregate microenvironment through a combination of production, consumption and regeneration processes and that oscillations in biomass and dissolved nutrients would occur in classical predatoryprey pattern. I have recorded such oscillations in bacterial numbers followed by microzooflagellates here. However, these defined systems did not have any photosnythesizing component.

Since (in terms of energy flow) transfer of a small amount of the microbial macro-aggregates directly to the macro food web would be equivalent to the transfer of orders of magnitude higher amounts of free (individual) microorganic biomass through the multistep Inicrobial food loop eventually to the macro food web, bacteria possibly play a key role in the transfer of carbon and energy to higher trophic levels. While the phenomenon of aggregate synthesis may be expected to be of considerable magnitude in coastal waters where macrophytes contribute significant quantities of detritus as well as dissolved material (Mann, 1982; Linley and Newell, 1984), we have no information of its role (involving phytoplankton debris, fecal material, etc.) in the upper mixed layer of the oceans. In other words, presently, we do not known how much these macroaggregates mean to the benthic and pelagic fisheries.
Microbial macroparticulate matter synthesis may be the most important phenomenon affecting transfer of materials and energy from the micro to the macro food webs in the sea. The earlier contention of ecologists that physico-chemical production of POM from DOM accounts for the calculated shortfall in particulate food material available to the consumers in the sea seems questionable in the light of the present findings. It may be that bacterial macroparticulate matter synthesis and its direct transfer to the macro food webs, which has not been adequately accounted for, are responsible for the above mentioned 'shortfall'. Only further investigations on the quantitative role these microbial macroaggregates play in the sea will answer this question.

Acknowledgements. This study has greatly benefited from discussions with L. R. Pomeroy, He also kindly commented on the draft manuscript. Considerable technical help from Kevin Fowler and Shirley Nishino is gratefully acknowledged. This work was made possible from support through the grant OCE 8110707 from the National Science Foundation and contract DE-AS09-76EV00639 from the U.S. Department of Energy to L. R. Pomeroy.

\section{LITERATURE CITED}

Aldredge, A. L., Cox, J. L. (1982). Primary productivity and chemical composition of marine snow in surface waters of the Southern California Bight. J. mar. Res. 40:517-527

Azam, F., Hodson, R. E. (1977), Size distribution and activity of marine microheterotrophs. Limnol. Oceanogr. 22: 492-501

Barber, R. T. (1966). Interaction of bubbles and bacteria in the formation of organic aggregates in sea water. Nature, Lond. 211: 257-258

Batoosingh, E., Riley, G. A., Keshwar, B. (1969). An analysis of experimental methods for producing particulate organic matter in sea water by bubbling. Deep Sea Res. 16: 213-219

Baylor, E. R., Sutcliffe, W. H., Jr. (1963). Dissolved Organic Matter in sea water as a source of particulate food. Limnol. Oceanogr. 4: 369-371

Blanchard, D. C., Syzdek, L. D. (1972). Concentration of bacteria in jet drops from bursting bubbles. J. geophys. Res. 77 (27): 5087-5099

Busch, P. L., Stumm, W. (1968). Chemical interactions in the aggregation of bacteria bioflocculation in waste treatment. Environ. Sci. Technol. 2 (1): 49-53

Carlucci, A. F., Williams, P. M. (1965). Concentration of bacteria from sea water by bubble scavenging. J. Cons. perm. int. Explor. Mer 30: 28

Cauwet, G. (1978). Organic chemistry of sea water particulates - concepts and developments. Oceanologica Acta 1 (1): 99-105

Cauwet, G. (1981). Non-living particulate matter In: Duursma, E. K., Dawson, K. (ed.) Marine organic chemistry. Elsevier Oceanographic Ser. 13: 71-89

Ducklow, H. W., Kirchman, D. L. (1983). Bacterial dynamics and distribution during diatom bloom in the Hudson River Plume, USA. J. Plankton Res. 5 (3): 333-355

Ducklow, H. W., Mitchell, R. (1979). Composition of mucus released by coral reef coelenterates. Limnol. Oceanogr 24: $706-714$ 
Fenchel, T (1970). Studies on the decomposition of organic detritus derived from the turtle grass Thalassia testudinum. Limnol. Oceanogr. 15: 14-20

Fenchel, T., Jorgensen, B. B. (1977). Detritus food chains of aquatic ecosystems: the role of bacteria. In: Alexander, $M$. (ed.) Advances in microbial ecology, Vol. 1. Plenum Press, New York, p. 158

Goldman, J. C. (1983). Oceanic nutrient cycles. In: M. J. Falsham (ed.) Flow of energy and carbon in marine ecosystems: theory and practice. Plenum Press, New York

Gottfried, M., Roman, M. R. (1983). Ingestion and incorporation of coral-mucus detritus by reef zooplankton. Mar Biol. 72: 211-218

Hobbie, J. E., Lee, C. (1979). Microbial production of extracellular material: importance in benthic ecology. In: Tenore, K. R., Coull, B. C. (ed.) Marine benthic dynamics. B. W. Brausch Lib. in Mar. Sci. No. 11: 341-346

Hobbie, J. E., Daley, R. J., Jasper, S. (1977). Use of nucleopore filters for counting bacteria by epifluorescence microscopy. Appl. environ. Microbiol. 33: 1225-1228

Hodson, R. E., Maccubin, A. E., Pomeroy, L. R. (1981). Dissolved adenosine triphosphate utilization by free-living and attached bacterioplankton. Mar. Biol, 64: 43-51

Jensen, L. M., Sondergaard, M. (1982). Abiotic formation of particles from extracellular organic carbon released by phytoplankton. Microb. Ecol. 8: 47-53

Johannes, R. E. (1967). Ecology of organic aggregates in the vicinity of a coral reef. Limnol. Oceanogr 12: 189-195

Johnson, B. D., Cooke, R. C. (1980). Organic aggregate formation resulting from the dissolution of bubbles in sea water. Limnol. Oceanogr. 25: 653-661

Kirchman, D., Mitchell, R. (1982). Contribution of particle bound bacteria to total microheterotrophic activity in five ponds and two marshes. Appl. environ. Microbiol. 43 (1): 200-209

Krank, K., Milligan, T. (1980). Macroflocs: production of marine snow in the laboratory. Mar. Ecol. Prog. Ser. 3 $19-24$

Linley, E. A. S., Newell, R. C. (1984). Estimates of bacterial growth yields based on plant detritus. Proc. Detritus Symp. Skidaway Inst. USA (in press)

Mann, K. H. (1982). Seaweed-based systems. In: Mann, K H. (ed.) Ecology of coastal waters. Blackwell, Oxford, p. 53-82

Menzel, D. W. (1966). Bubbling of sea water and the production of organic particles: a re-evaluation. Deep Sea Res 13: 963-966

Menzel, D. W., Vaccaro, R. F. (1964). The measurement of dissolved organic and particulate carbon in sea water Limnol. Oceanogr. 9: 138-142

Moriarty, D. J. W. (1979). Biomass of suspended bacteria over coral reefs. Mar. Biol. 53: 193-200

Newell, R. C., Lucas, M. I., Linley, E. A. S. (1981). Rate of degradation and efficiency of conversion of phytoplankton debris by marine microorganisms. Mar. Ecol. Prog. Ser. 6: $123-136$

Nishizawa, S. (1969). Suspended material in the sea. 2. Reevaluation of the hypotheses. Bull. Plankton Soc. Japan 16 (2): $1-42$

Paerl, H. W. (1973). Detritus in Lake Tahoe: structural modification by attached microflora. Science, N. Y. 180:496-498

Paerl, H. W. (1974). Bacterial uptake of dissolved organic matter in relation to detrital aggregation in marine and freshwater systems. Limnol. Oceanogr. 19: 966-972
Paerl, H. W. (1975). Microbial attachment to particles in marine and freshwater systems. Microb. Ecol. 2: 72-83

Paerl, H. W. (1978). Microbial organic carbon recovery in aquatic ecosystems. Limnol. Oceanogr 23 (5): 927-935

Parsons, T R. (1963). Suspended organic matter in sea water In: Sears, M. (ed.) Progress in oceanography, Vol. 1 Pergamon Press, New York, p. 205-239

Pedros-Alio, C., Brock, T D. (1983). The importance of attachment to particles for planktonic bacteria. Arch. Hydrobiol. 98 (3): $354-379$

Pomeroy, L. R. (1974). The ocean's food web, a changing paradigm. BioScience 24:499-504

Pomeroy, L. R. (1984). Significance of microorganisms in carbon and energy flow in aquatic ecosystems. In: Klug, M. J., Reddy, C. A. (ed.) Current perspectives in microbial ecology. Am. Soc. Microbiol., Washington (in press)

Pomeroy, L. R., Johannes, R. E. (1968). Occurrence and respiration of the ultraplankton in the upper $500 \mathrm{~m}$ of the ocean. Deep Sea Res. 15: 381-391

Qasim, S. Z., Sankaranarayanan, V. N. (1970). Production of particulate matter by the reef on Karavatti Atoll. Limnol Oceanogr. 15: 574-578

Riley, G. A. (1963). Organic aggregates on sea water and the dynamics of their formation and utilization. Limnol. Oceanogr. 8: 372-381

Riley, G. A. (1970). Particulate organic matter in sea water. Adv. mar Biol. 8: 1-118

Robertson, M. L., Mills, A. L., Zieman, J. C. (1982). Microbial synthesis of detritus-like particulates from dissolved organic carbon released by tropical seagrass. Mar. Ecol. Prog. Ser 7: 279-285

SAS User's Guide (1982). Statistics. SAS Institute Inc., Cary, North Carolina

Seki, H. (1972). The role of microorganisms in the marine food chain with reference to organic aggregates. Mem. Ist. ital. Idrobiol. 29 (Suppl.): 245

Sheldon, R. W., Evelyn, T P. T., Parsons, T. R. (1967). On the occurrence and formation of small particles in sea water. Limnol. Oceanogr. 12: 367-375

Sieburth, J. McN. (1965). Organic aggregation in sea water by alkaline precipitation of inorganic nuclei during the formation of ammonia by bacteria. J. gen. Microbiol. 41: 20

Silver, M. W., Shanks, A. L., Trent, J. D. (1978). Marine snow: microplankton habitat and source of small-scale patchiness in pelagic populations. Science, N. Y. 201: 371-373

Silver, M. W., Aldredge, A. L. (1981). Bathypelagic marine snow: deep-sea algal and detrital community. J. mar. Res. 39 (3): $501-530$

Sorokin, Yu. I. (1974). Bacteria as a component of the coral reef community. Proc. 2nd Int. Coral Reef Symp. 3-10

Weber, M. E., Blanchard, D. C., Syzdek, L. D. (1983). The mechanism of scavenging water borne bacteria by rising bubbles. Limnol. Oceanogr. 28 (1): 101-105

Wetzel, R. G., Rich, P. H., Miller, M. C., Allen, H. L. (1972). Metabolism of dissolved and particulate detrital carbon in a temperate hard-water lake. Mem. Ist. ital. Idrobiol. 29 (Suppl.): 185

Wiebe, W. J., Pomeroy, L. R. (1972). Microorganisms and their association with aggregates and detritus in the sea: a microscopic study. Mem. Ist. ital. Idrobiol. 24 (Suppl.): 325-352

Williams, P. J. LeB. (1981). Incorporation of microheterotrophic processes into the classical paradigm of the planktonic food web. Kieler Meeresforsch. Sonderh. 5: 1-28 